\title{
The geological and tourist attractions of the largest Australian cities and their surroundings
}

\author{
Izabela Jamorska \\ Nicholas Copernicus University in Torun', Faculty of Earth Sciences, \\ ul. Lwowska 1, 87-100 Toruń; \\ e-mail:iza1984@umk.pl
}
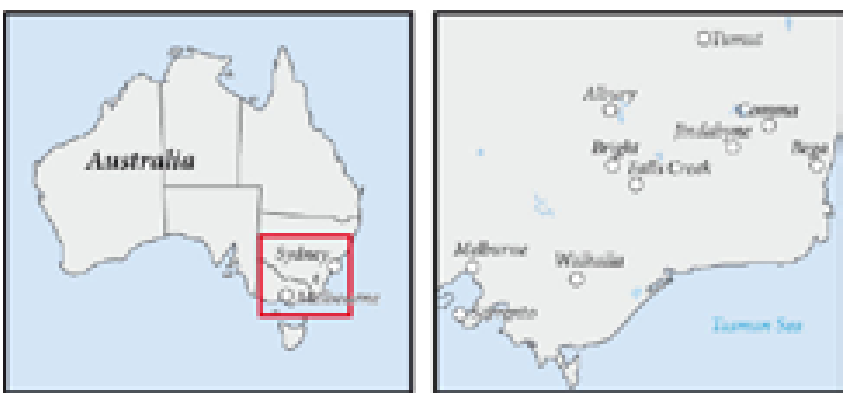

Abstract: Australia, labelled the continent of contrasts, is one of the most geologically interesting places in the world. Australia is home to some of the oldest rocks and minerals in the world. Some of the oldest parts of Australia are incredibly well preserved, with rocks that appear as though they could have formed yesterday. The majority of Australians live in coastal areas, because the interior of the country, called the Outback can be a very arid area with many deserts and a lack of water. The largest cities, like Sydney, Perth and Melbourne, are situated along the coast. Great distances between the cities are surprising to foreigners. In these areas, buildings or people are not the most interesting attractions. In fact, it is the geology that is most interesting.

Key words: geological attraction, rocks, biggest cities

\section{Introduction}

My journey to the Southern Hemisphere took almost thirty hours, and getting to know Australia had to take no longer than three weeks. My adventure started in Melbourne, Victoria state, in the south of the continent. The biggest cities of Australia, such as Canberra, Sydney and Perth, as well as the highest peak of the continent, Mount Kosciuszko (2228 meters above the sea level), marked the next stops on my itinerary (Fig. 1). The main objective of the expedition was to investigate the most interesting geological attractions of the biggest cities of Australia.

\section{A few words about geology}

The present coastline of the Australian continent began to take shape around 50 million years ago, after the breakup of the last supercontinent - Gondwana. The latest orogeny took place here 230 million years ago, in which alpine mountain ranges with snow-capped peaks were pushed up. Subsequently, there were minor orogenies, as a result of which low mountain ranges were uplifted.
The Australian continent is situated in the eastern part of the Indo-Australian lithosphere. The predominant part of Australia is occupied by the Precambrian platform (Australian) bordering in the east with the early Paleozoic structure of the Flinders Ranges and Broken Hill as well as the late Paleozoic structure of the Great Dividing Range (Mizerski, 2006).

Australia is home to some of the oldest rocks in the world, some dating back to more than 3,7 Ga. The oldest minerals can also be found here, such as the detrial zircon grain from Western Australia, with an age of more than 4,4 Ga.

The topography of the continent of Australia is subdued. With an average elevation of only $325 \mathrm{~m}$, Australia is the lowest of all continents. Without major mountains, Australia's river system have low and erratic flow rates compared with those on other continents. The highest point on the continent, Mt Kosciuszko, is only $2228 \mathrm{~m}$ asl. The lowest point is Lake Eyer at around $15 \mathrm{~m}$ bsl (Blewett, 2012).

The geological processes occurring here have made Australia a genuine treasure chest for exploration. In all the parts of Australia, a host of different mineral resources can be found.

The Victoria State became famous for its gold and crude oil deposits under the bedrock of the Bass Strait in the 1850s. New South Wales has the biggest deposits of the blended ores of silver, zinc and lead and sizeable coal deposits. The south of the continent has rich deposits of copper and uranium. The village of Coober Peddy, located $850 \mathrm{~km}$ north from Adelaide, provides around $85 \%$ of the world's demand for opals. Western Australia is the richest area in minerals not only in Australia, but also in the whole world. This territory abounds in deposits of gold, nickel, iron and diamonds. The waters on the west coast of Australia support the vegetation of gulf pearl oysters (Broom). The north of the continent has the richest deposits of bauxite in the world (Cape York Peninsula) and possesses deposits of natural gas in the sandstones in the bedrock of the Timor Sea.

\section{Victoria}

Victoria is an Australian state, situated at the southern end of the Great Dividing Range, which stretches along the east coast and terminates near Ballarat. The highest mountains in Victoria (just under $2000 \mathrm{~m}$ ) are the Victorian Alps, located in the northeastern area. The area of extensive volcanism in central and southwestern Victoria, is where one can find numerous extinct volcanoes and volcanic lakes. The most recent volcanic activity was at Mt Eccles, which last erupted a few thousand years ago. Large basaltic lava flows are present on the western side of Melbourne and in the southwest of the state. Central 
and western Victoria comprise world-class, vein-hosted gold deposits, hosted mostly in the extensive Ordovician Turbidites. The southeast of the state has enormous brown coal fields. The low, flat northwestern part of the state bordering the Murray River was once the bed of an ancient sea. The land here is much afflicted with salinity (Birch, 2003).

Victorian geological history can be divided into three major episodes: the Neoproterozoic to the Early Carboniferous, the Late Carboniferous to the Mid-Mesozoic and the Mid-Mesozoic to the present day.

\section{Melbourne}

Melbourne is the biggest city in Victoria, which is the smallest and the greenest state in Australia. Numerous traces of former volcanism, such as extinct volcanoes and crater lakes, can be found there. The main landmarks are the skyscrapers of the Central Business District (CBD), including the Rialto Towers and the Commercial Bank of Australia. Apart from the modern buildings of the Central Business District, Victorian style buildings predominate, dating back to the nineteenth century. Melbourne is inhabited by an ethnic makeup of mainly Greeks, Italians and Asians, whose cultural influences are noticeable in the whole city. Queen Victoria Market is an important site on the map of Melbourne for true gourmet. It is a bazaar that goes back to the 1870 s, where you can buy the freshest foods straight from the nearby farms.
The Yarra River flows through the city, and many impressive buildings such as the Railway Station and the Crown Casino be admired from its banks. The neighborhood of Melbourne is famous for numerous vineyards, where visitors/guests are cordially invited to taste home-made wines in picturesque scenery.

\section{Geology of the Mornington Peninsula}

The Mornington peninsula, a relatively small area, has many of the geological formations found in other parts of Victoria. The bedrock of the Mornington Peninsula (Fig. 2) is well exposed along its axis, and consists of strongly folded Ordovician and Silurian sediments, intruded by granitic plutons of probably Upper Devonian age. The Peninsula is essentially a horst with a prominent graben to the west (the Port Phillip Sunkland) and a lesser negative area to the east (the Western Port Sunkland). The strike of the major faults is NNE-SSW, parallel to the trend of the folded Paleozoic sediments. However several cross faults and diagonal faults are known (Keble, 1950). Additionally, some faults have shown recurrent movement and probably date back to the Paleozoic. Many faults were active during the Tertiary. This movement has persisted to recent times, with earthquake tremors originating in the Selwyn Fault zone. This fault, on the western edge of the Peninsula, is very important, with a throw of over $600 \mathrm{~m}$ during the Cenozoic (Gostin, 1966).

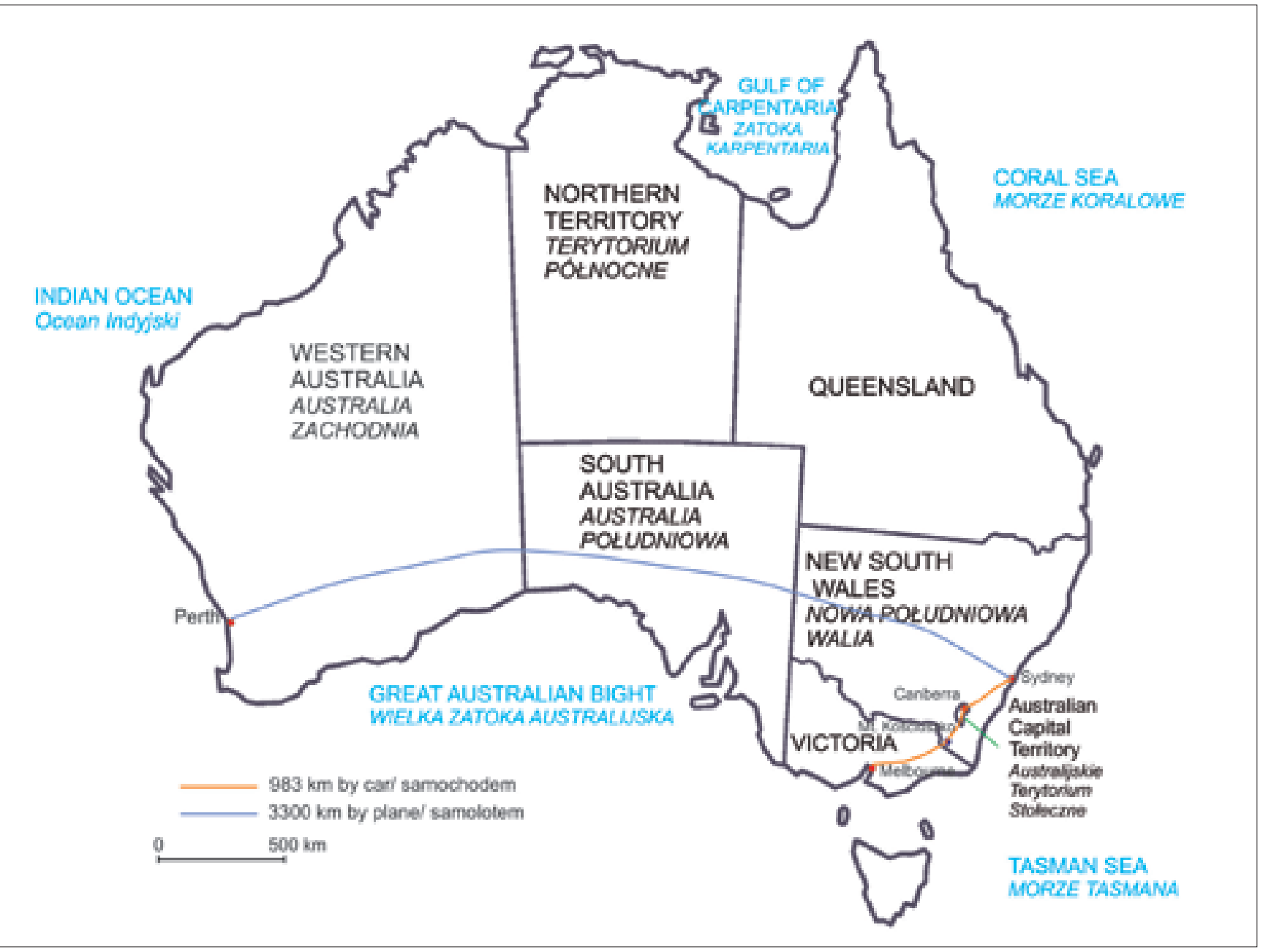

Fig. 1. Map of the trip location of the Australia's biggest cities 


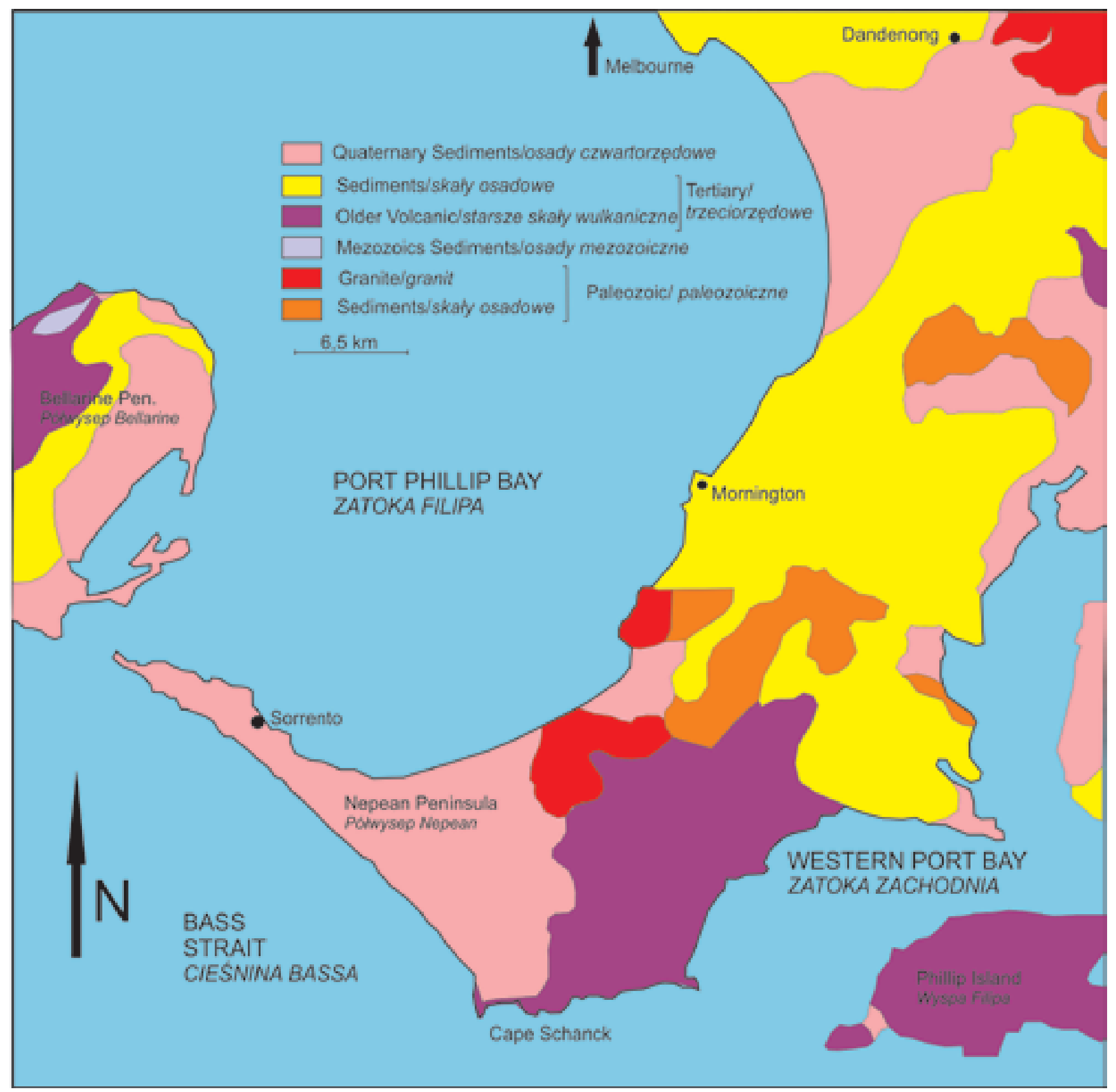

Fig. 2. Geological map of the Mornington Peninsula (after Keble, 1950, modified)

The base - rock of the Peninsula is Ordovican and Silurian strata. The Ordovician sediments are estimated to be some $3000 \mathrm{~m}$ thick, and consist of silty, generally fine grained sandstones, graptolitic shales and slates, in a monotonous thin-bedded sequence, deposited mainly under deep marine, anaerobic conditions. The succeeding Silurian sediments consist of lighter colored mudstones, shales, medium to coarse grained sandstones and a conglomerate. Fossils include brachiopods, crinoids polyzoa and some graptolites.

The Mesozoic sediments of the Peninsula occur in a very small in-faulted remnant, exposed on the shore platforms at Sunnyside Beach. They consist of fluviatile arkoses sandstones and grey mudstones, with a well preserved Lower Cretaceous flora (Gostin, 1966).
The Tertiary sedimentary sequence on the Peninsula is generally flat-lying and thin, but thickens considerably into flanking troughs. This is particularly evident into the Port Phillip Sunkland, where it is at least $350 \mathrm{~m}$ thick beneath a Quaternary cover of $140 \mathrm{~m}$.

Deposition may be regarded as having occurred in three phases; an early Tertiary terrestrial and volcanic phase; a marine transgression, during the Miocene (limestones, marls and marine clays were deposited); and a final regressive phase, leading to a return to terrestrial sedimentation in the late Tertiary. Afterwards, a period of intense leaching and ferrugination occurred. As well as being intercalated in the sediments of the early Tertiary deposition phase, basalts (Older Volcanics) cover much of the southern part of the Mornington Peninsula, 
where they reach great thicknesses and form impressive cliffs along the Cape Schank-Flinders-Phillip Island coastline.

In the southwest, the Nepean Peninsula extends westwards towards Sorrento and Portsea. This region of low and hummocky topography consists mainly of Pleistocene dune limestone, developed as a bar across the Port Phillip Sunkland. It is thinly mantled by recent dunes and swamp deposits (Keble, 1950).

The Mornington Peninsula is located around two hours' drive south of Melbourne. It is a very popular place among the inhabitants of Melbourne. Here the Mornington Peninsula National Park occupies an area of 25,000 acres. The shoreline of the Port Philip Bay hosts many beautiful beaches washed by calm waters, which contrasts sharply with the rugged coastline of the ocean (Fig. 3). This is a result of the destructive influence of salt water, which shapes diverse forms in basalt rocks. The best place to observe this phenomenon is the Bushrangers Bay, where sandy beaches are surrounded by basalt cliffs. Volcanic rocks can also be seen At Cape Shanck (Fig. 4).

The trail marked here begins with wooden steps, which lead to a gravel beach and a ledge. It looks out over a geological formation commonly known as the Pulpit Rock and Devil's Desk (Fig. 5), formed during millions of years in volcanic rocks (www.parkweb.vic.gov.au).

Numerous hollows in the rocks are filled with crystal-clear water, which flows into them during tides (Fig. 6). There are many dormant volcanoes along the eastern margin of
Australia. These form the Newer Volcanic Group, which is a chain of mostly mafic volcanic rocks that erupted along the Great Divide. These rocks stretch from Cape York Peninsula to southern Victoria and South Australia (Blewelt, 2012).

In the 1970s, Cape Shanck was not yet a part of the park. The destruction of this place was caused by the unrestricted activity of the volcanic rocks along with the erosive activity of the water. At the beginning of the 1980s, the Victoria State Government decided to protect this area and adapt it for tourism. Since 1988, the area has been a part of the National Park (www.parkweb.vic.gov.au).

Apart from geological formations, a lighthouse is the main tourist attraction of this site. It was erected in 1859 and constitutes a fine example of nineteenth-century architecture. Currently, it houses a museum and offers lodgings for tourists.

\section{Point Nepean}

Point Nepean National Park constitutes a part of the Mornington Peninsula National Park. It is one of the most beautiful sites that can be found in the whole of Victoria State. The diversity of the scenery and its history contribute to the beauty and attractiveness of this place. Point Nepean played a major part during World War II as the place of fierce military defense of Victoria State as well as a quarantine district. The park is located on the very tip of the Mornington Peninsula withwonderful views to be found of the Bass Strait, Rip and Port Phillip Bay (Fig. 7).

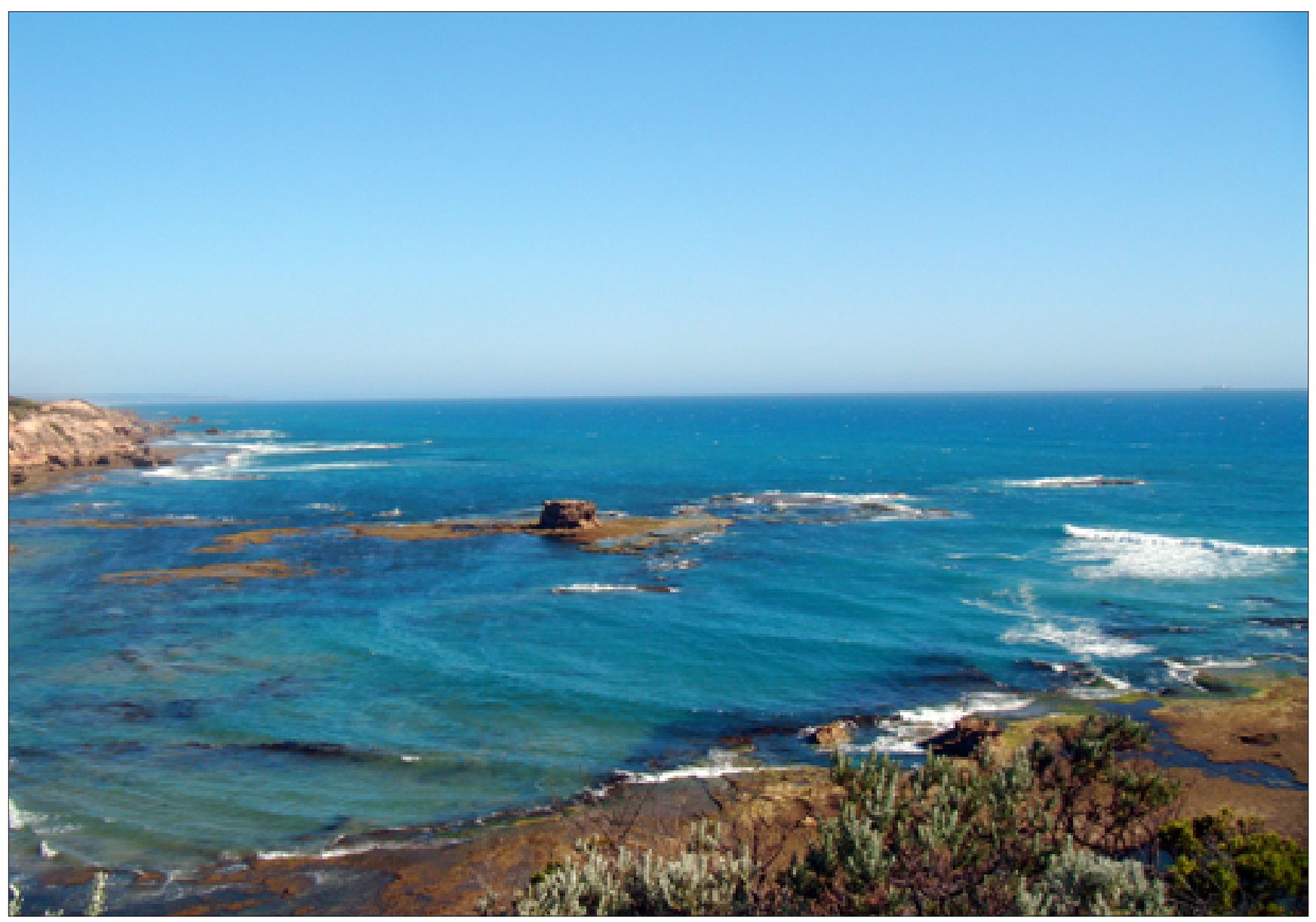

Fig. 3. Sorrento Back Beach, photo I. Jamorska 


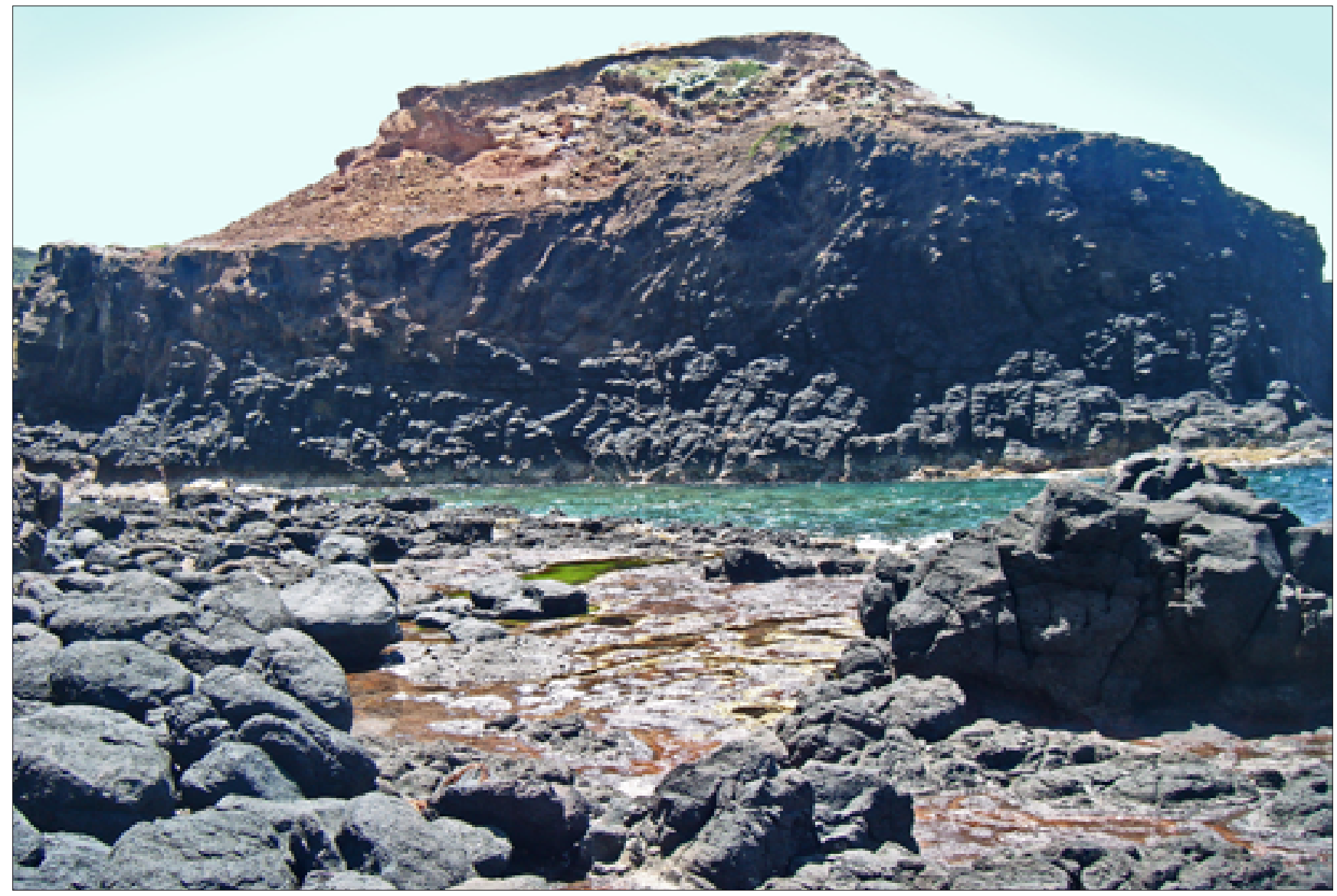

Fig. 4. Cape Schanck - layers of lava and sea shells: the dark blue - black bands of hard rock are basalt; the lighter yellow bands on top of the basalt are the much younger porous limestone, photo I. Jamorska

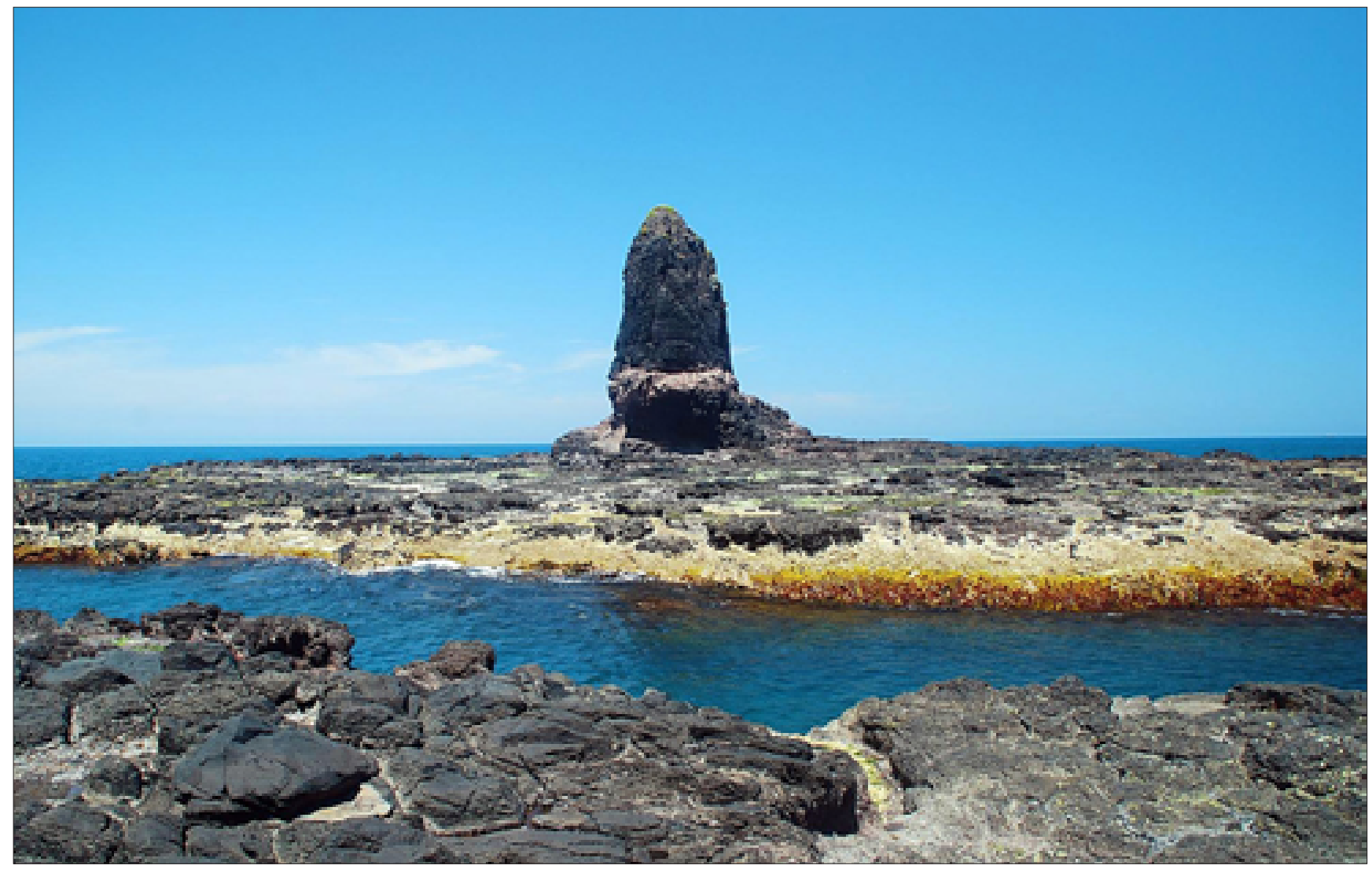

Fig. 5. Cape Schanck - Pulpit Rock - geological formations formed durign millions of years in volcanic rocks, photo I. Jamorska 


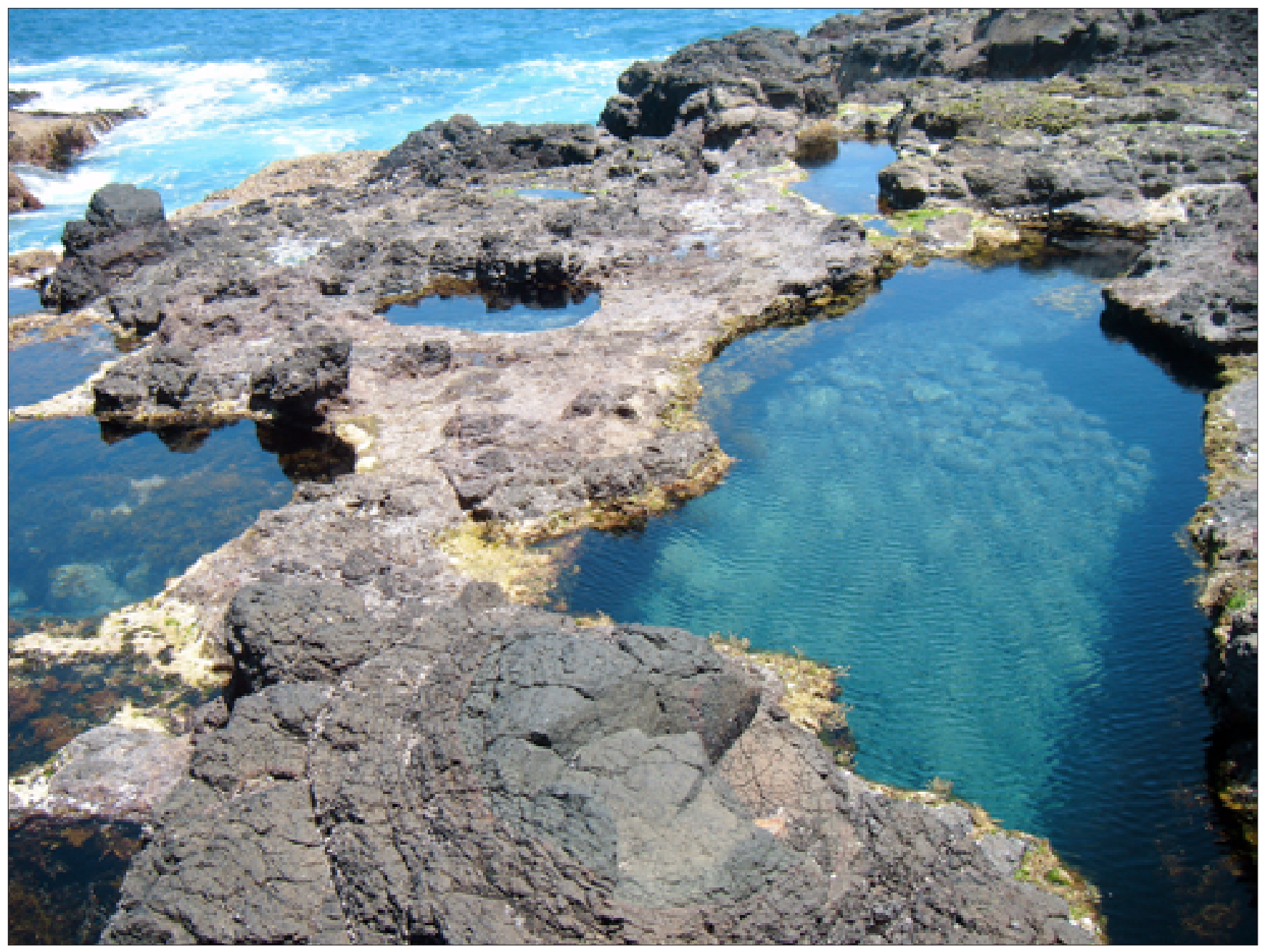

Fig. 6. Cape Schanck - pools with marine life, photo. I. Jamorska

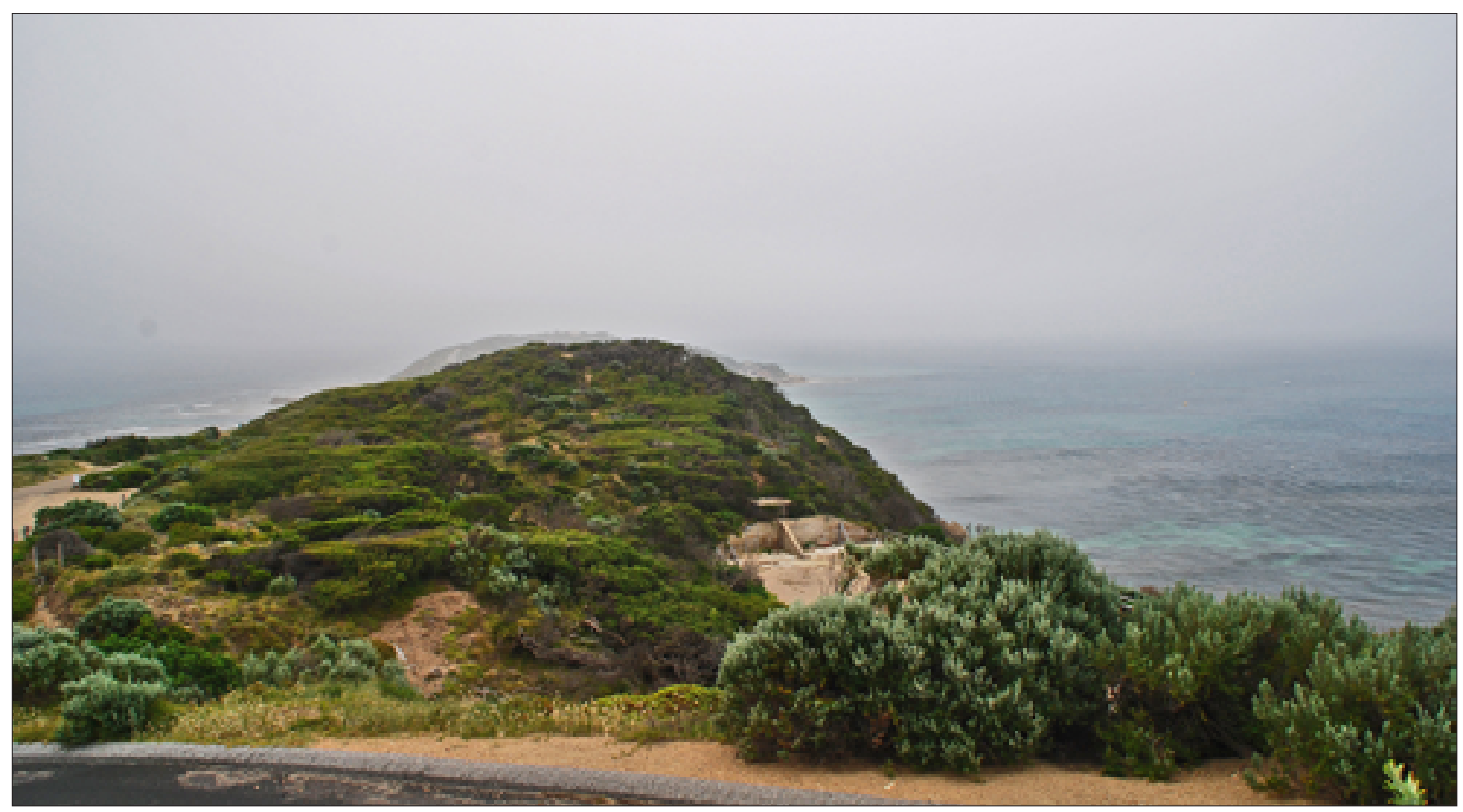

Fig. 7. Port Philip Bay, photo I. Jamorska 
For over a century, this site was inaccessible to civilians, due to the presence of the military. The Point Nepean Quarantine Station is a place of great historical significance. Established in 1852, it was the major place for quarantine purposes in Victoria until 1979 and was closed down in 1980. The site was used by the Army as a School of Army of Health from 1985-1998. In 1999, the Quarantine Station buildings were used to accommodate Kosovo refugees.

\section{From Victoria to New South Wales}

The geological history of New South Wales is very complex and spans almost 2 billion years. During this time, there have been multiple phases of active continental growth, involving periods of widespread volcanic activity, sedimentation, granite intrusion and intense folding and faulting, resulting from the processes of plate tectonics. These geological processes led to the formation of new or additional crustal areas in the form of mountain chains or orogenies. During this time, these mountain chains in NSW have been denudated to produce the overall subdued topography we now see. NSW contains four orogenies and many younger areas of sedimentary cover (www.nsw.gov.au).

New South Wales consists of seven main regions: Lachlan Fold Belt, the Hunter-Bowen Orogeny or New England Orogen (NEO), the Delamerian Orogeny, the Clarence Moreton Basin, the Great Artesian Basin, the Sydney Basin, and the Murray Basin.

\section{Sydney}

Sydney, the largest Australian's city, is located in the region of Sydney Basin. The Sydney Basin is a major structural basin containing a thick Permian-Triassic (290 Ma-200 Ma) sedimentary sequence, that is a part of the much larger Sydney-Gunnedah-Bowen Basin. This Basin extends all the way from Durras Lake, in the south of New South Wales, to the north to Bowen in Queensland, a distance of several thousand kilometers. The Sydney Basin is economically important as it contains all the known large coal-fields in New South Wales and Queensland (http://australianmuseum.net.au).

Contrary to popular belief Sydney is not the capital city of Australia. With the population of over 3 million people and the area of 4,074 square kilometers, Sydney is the biggest and the most bustling Australian metropolis.

The city has around seventy wonderful beaches, two of which are especially popular: Manly Beach and Bondi Beach. The major disadvantage of the city are its narrow streets, designed in the nineteenth century mainly for pedestrians and horses. Victorian style houses from the most luxurious historical district of Paddington, with decorative iron balconies and wooden shutters in windows, also date back to this period. Extensive parklands in the centre and on the outskirts of the city more than make up for the narrow streets. These vast green areas have nearly been preserved intact in their natural state. In principle, most of them have footpaths, cycling lanes and horse avenues running along small lakes and ponds. Eucalyptus trees and flocks of birds, primarily black swans and cockatoo parrots so popular in Sydney, are almost ubiquitous in the city. The Opera House (Fig. 8) and the Harbour Bridge are the central symbols of the city. These two world-famous landmarks add charm to Port Jackson (also referred to as
Sydney Harbour). Despite the size of the city and the maze of the street pattern, moving around Sydney is not complicated. The two transportation centers are the Railway Station and Circular Quay. From there, one can explore all the nooks and crannies of Sydney taking a train, bus or ferry. The best way to appreciate the beauty of the Bay is a cruise by ferry departing from Circular Quay. It is also recommendedto go on a cruise to Manly - the suburb stretching between the northern shore of the Bay and the Tasman Sea coast. During the 30 minute ferry cruise, one can admire numerous parks and botanical gardens, sandstone rocks guarding the entrance to the Bay. During the return cruise, one can appreciate the splendid vista of the spectacular Opera House and the Harbor Bridge.

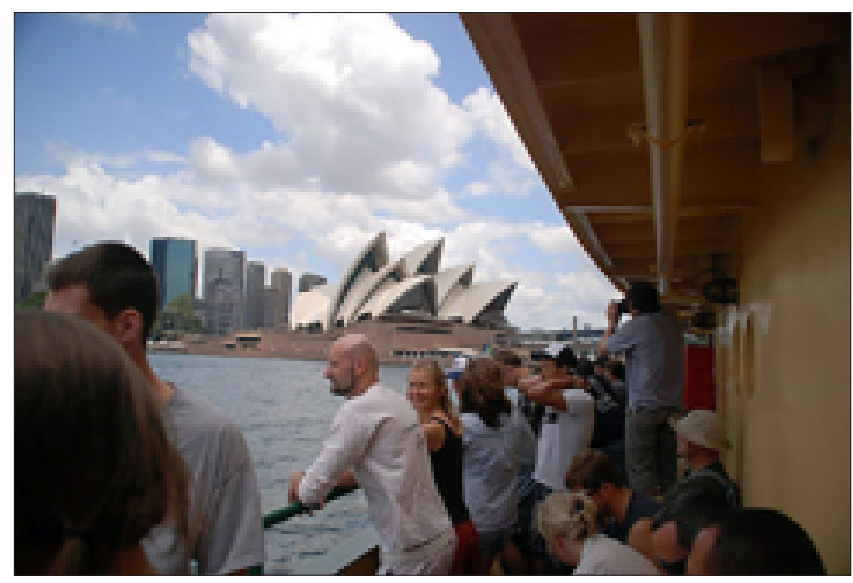

Fig. 8. Cruise by ferry departing from the Circular Quay to Manly Beach - Opera House, photo I. Jamorska

\section{The Australian Alps and Mt Kosciuszko}

The Australian Alps are the highest part of a larger entity, the Eastern Highlands of Australia, which runs along the coast from northern Queensland to Victoria. Because the Australian Alps cover a large area, they display a wide range of rock types and complex geological history spanning 520 million years (Fig. 9).

The oldest rocks in the alpine region are basalt lavas which erupted onto the deep ocean floor in the Cambrian period. These occur in Victoria in the Howqua Valley. During the next 80 million years, a vast area of the ocean floor was covered by a thick blanket of sand and mud, turning in the course of time into the sedimentary rocks: sandstone and mudstone. These rocks form much of the Australian Alps.

During this time, a large chain of volcanic islands formed in what is now New South Wales from the eruptions of basalt and andesine lava. The volcanoes of the Silurian and Devonian periods were quite explosive, erupting towering clouds of hot volcanic ash, which formed a rock known as ignimbrite. In Victoria, this type of rock occurs at lake Mountain and the Snowy River area. In these periods, the geography of southeastern Australia was complex with small seas and large to small islands. Some islands developed coral reefs along their edges, which, over time, became limestone. About $360 \mathrm{Ma}$, much of southeastern Australia was a mountain range. This range had nothing to do with the present-day Australian Alps, and was part of an ancient cycle of plate tectonic movements. 
After the last episode of folding, about $340 \mathrm{Ma}$, southeastern Australia entered a 200 million year period during which not much happened, geologically speaking.

Australia was part of the supercontinent of Gondwana, lying in the interior of the landmass. The mountain ranges were slowly worn down to a low laying plaine and very few rocks of this period are preserved in the alpine region. Around $300 \mathrm{Ma}$, Australia was closeto the South Pole. Ice sheets covered much of southern Australia. Glacial deposits are preserved outside the alpine region in Victoria and New South Wales. About $130 \mathrm{Ma}$, stirrings in the deep mantle began to break up eastern Gondwana. Australia began the long processof breaking away from Antarctica and Zelandia. The process began with magma moving upwards into the lithosphere, causing it to heat and expand upwards, forming a dome-shaped plateau, running along what is now the east coast of Australia. Zelandia moved eastwards, while Tasmania only moved a short distance southwards forming the shallow Bass Strait.

The Australian Alps were left behind as a remnant of the original plateau, with a steep seaward side and a gentle slope towards the inland. By $65 \mathrm{Ma}$, the Australian Alps were probably not much higher than they are today. Since then, erosion has carved deep valleys into the plateau and rounded off the landforms. Over the last $50 \mathrm{Ma}$, basalt lava has erupted episodically over much the alpine region. The lava came out of small volcanoes and flowed across the landscape and down the valleys.

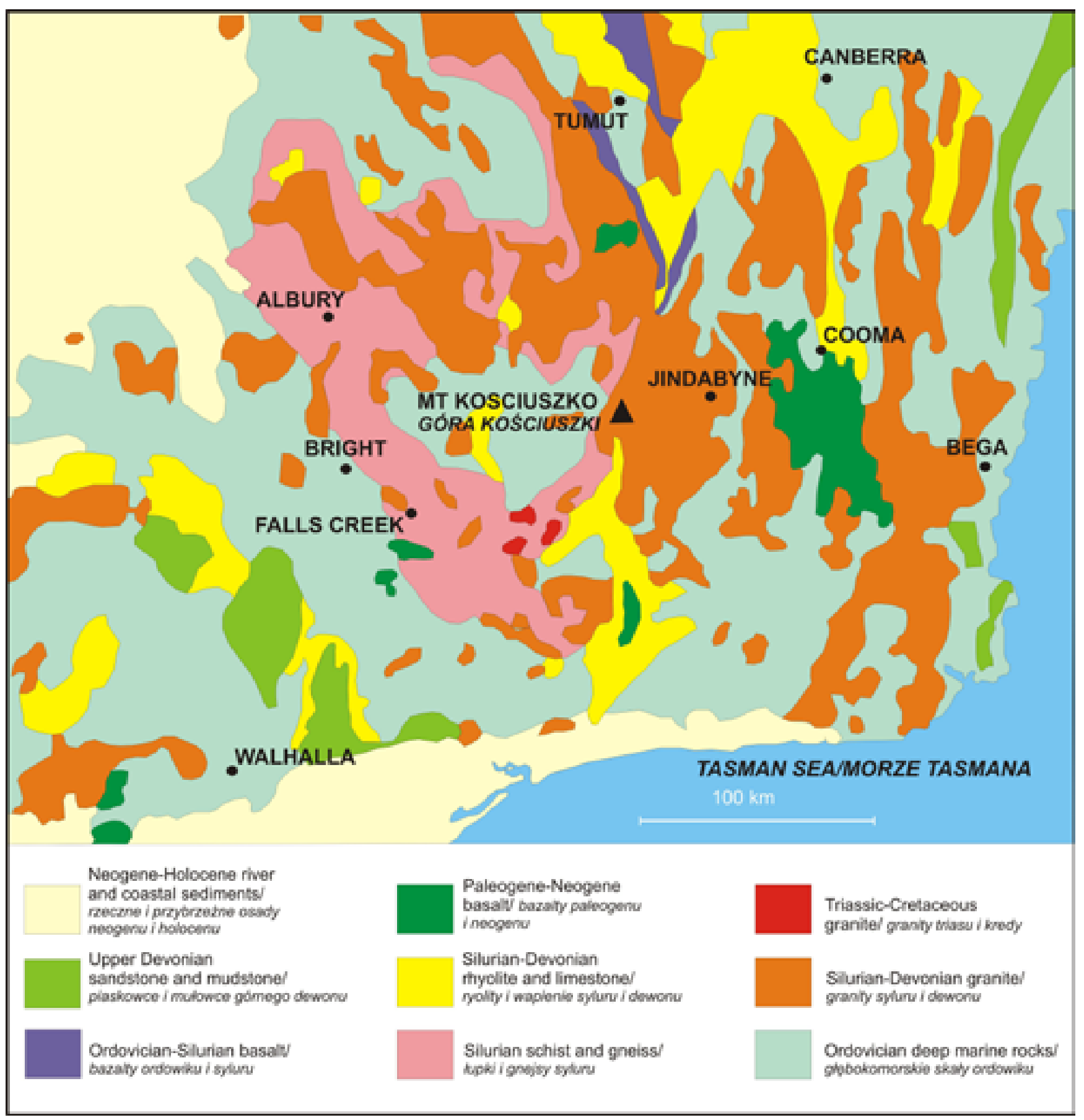

Fig. 9. Schematic geological map of the Mt. Kosciuszko (source: http://www.australianalps.environment.gov.au) 
Many of the high plains in Victoria are covered by basalt. Although the Alps were mostly in place by about $90 \mathrm{Ma}$, there have been several minor uplift episodes since then, in various parts of the Alps. These events have in many cases altered the course of rivers by tilting and faulting, in some case reversing their flow and sending them in new directions.

Most of the last 2 million years consists of the time of the global ice age, with ice caps forming on high ranges around the world. Because the Australian Alps are only of modest height (the highest point being Mt Kosciuszko at $2228 \mathrm{~m}$ ), glaciers were formed only in the highest parts (above $2000 \mathrm{~m}$ ) in the vicinity of Mt Kosciuszko. Several tarns and cirques remain. These result from glaciers scooping out hollows in the ground. An example of tarns, which filled the bottom of cirques after the ice melted about 12000 years ago. Is the Blue Lake. Some of the small valleys near Mt Kościuszko have $U$ shaped cross sections, typical of valleys carved by glaciers (www.australianalps.enviroment.gov.au).

The highest range of the Great Dividing Range consists of the Snowy Mountains the highest peak - Mt Kosciuszko (2228 m above sea level). The Snowy Mountains belong to Mt Kosciuszko National Park, which covers 6,900 square kilometers of mountains, overgrown with thick forest as well as a diversity of glacial and tarn lakes (Fig. 10) and blossoming meadows (Fig. 11). Mount Kosciuszko was named by the Polish traveler and explorer Pawel Edmund Strzelecki to honor great the Polish patriot Tadeusz Kosciuszko.

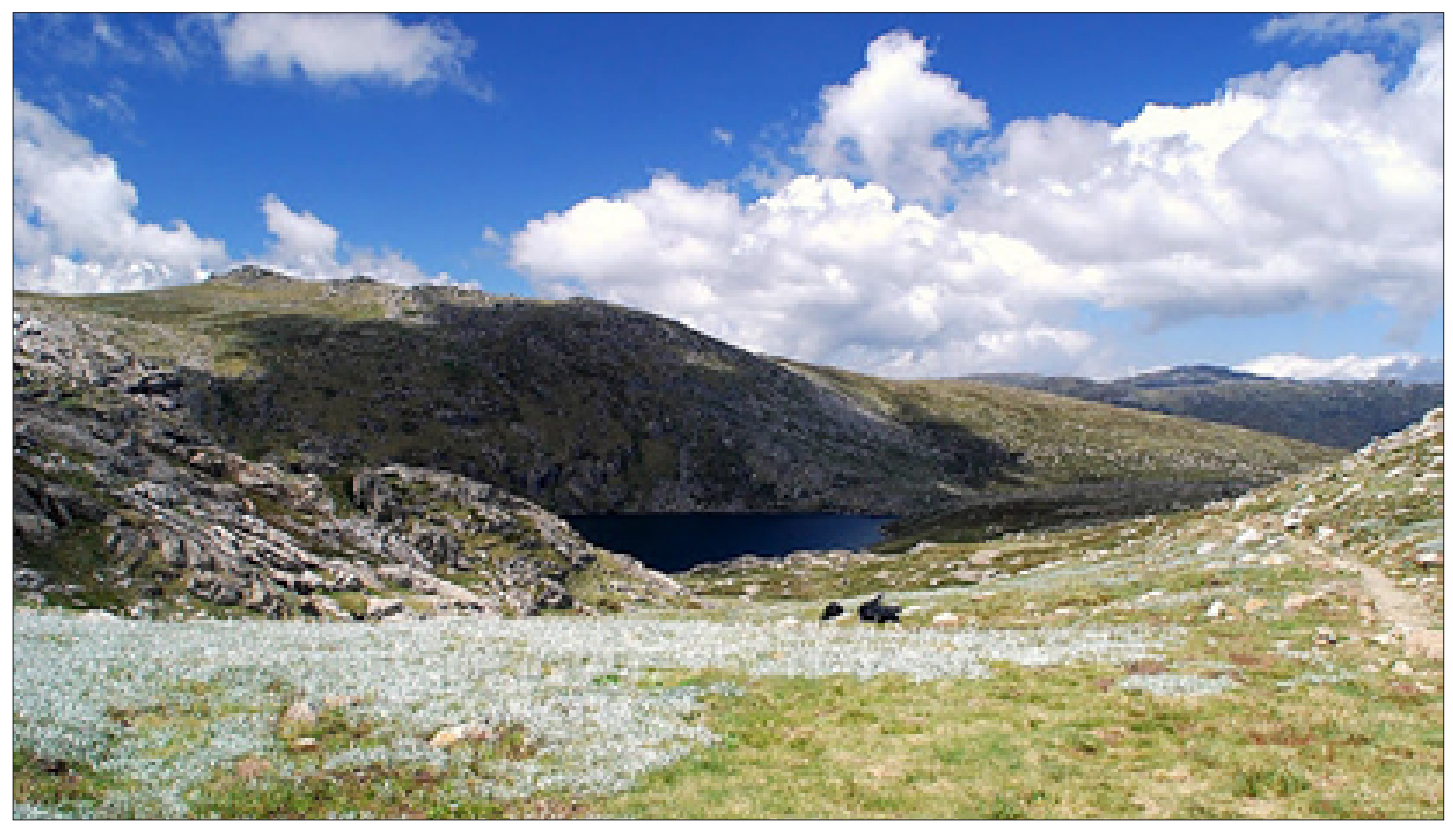

Fig. 10. Snow Mountains - glacial lake, photo I. Jamorska

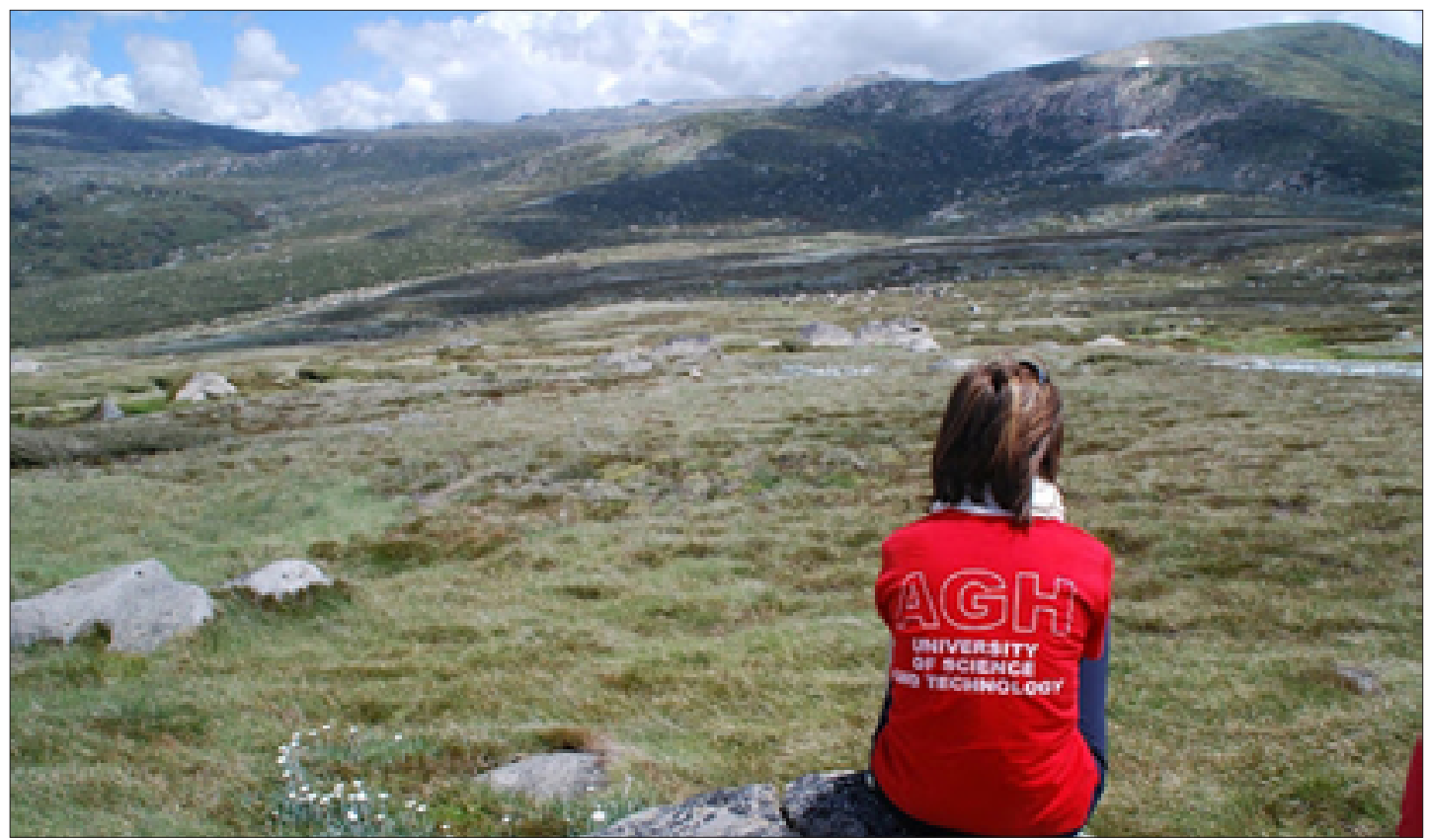

Fig. 11. Mt Kosciuszko National Park, photo I. Jamorska 


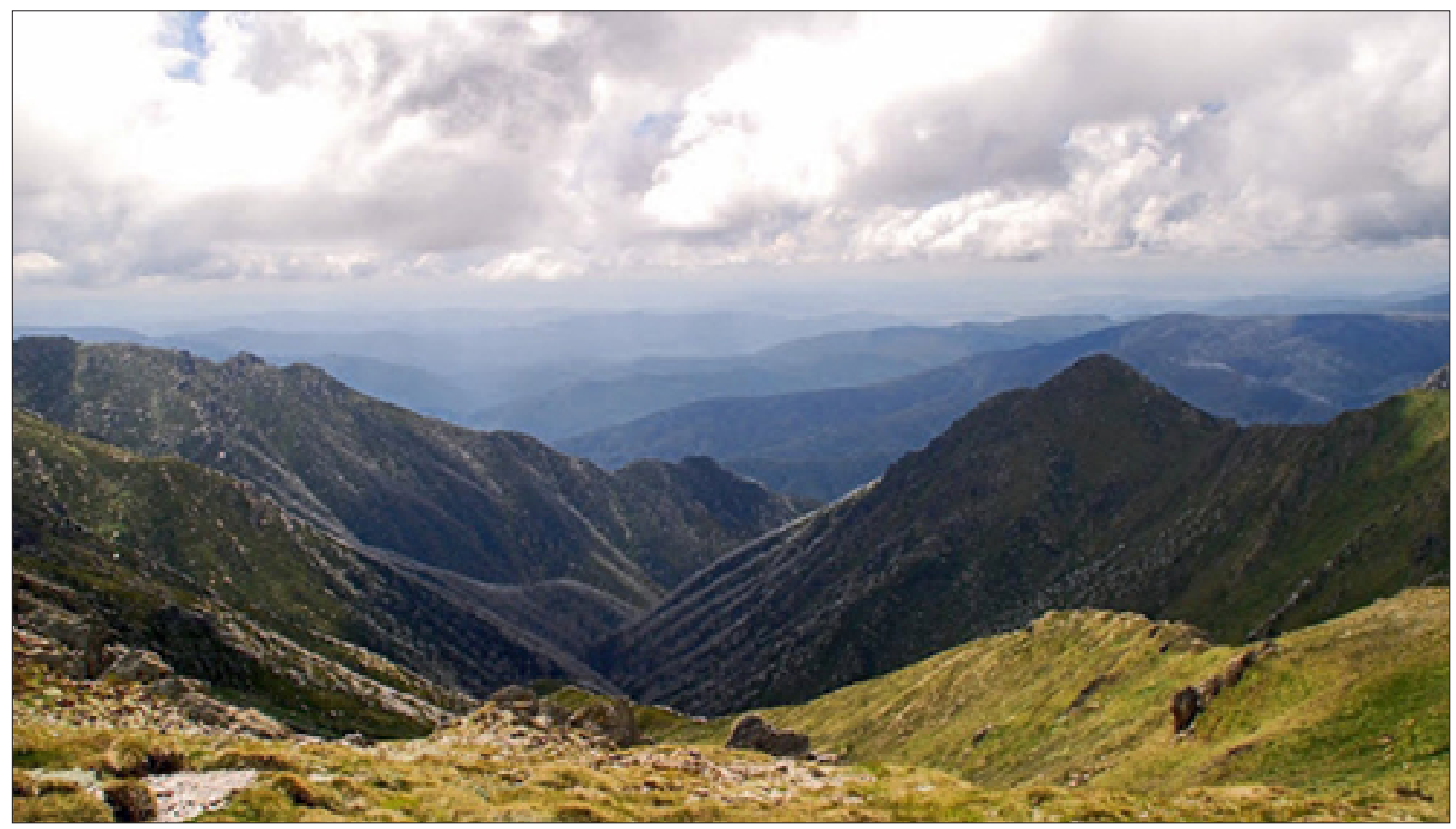

Fig. 12. View from the top of Kosciuszko Mountain (2228 metres above sea level), photo I. Jamorska

Climbing the highest peak of Australia does not pose a major challenge even for beginners. It is even possible to reach the summit by bicycle. The trails are well-marked and clearly described both on websites and notices planted along them. Jindabyne and Cooma are mountain resorts that serve as a perfect base for mountain trips.

The Mt Kosciuszko trail from Jindabyne leads through Charlotte Pass. The trip to the summit that starts among eucalyptus trees takes no longer than six hours. The upper parts of the mountains are no longer wooded and, therefore, beautiful mountain scenery (Fig. 12) can be admired through most of the climb to the top. The highest parts of the mountains are covered by rock rubble, a remnant of the ice age.

\section{Australian Capital District}

Canberra, the capital city of Australia, has been a wellplanned city since its origin. Although Australian states united in 1901, it took eight years before the appropriate site for the capital city was finally chosen. In 1911, a competition concerning the urban planning of the capital was announced. It was won by Walter Burley Griffin, a Chicago urban planner, whose concept envisioned the radiating development of the city in different directions from the edifice of the Parliament and artificial lake in its vicinity. The inland location of Canberra, far away from the ocean, $300 \mathrm{~km}$ away from Sydney and $660 \mathrm{~km}$ away from Melbourne, made the city rather unpopular among the Australians. It was not until
40 years after its establishment that people began to settle down there. The city planned for the population of 25,000 has recently exceeded 300 thousand inhabitants. The majority of Canberra's inhabitants are state dignitaries, diplomats and office clerks. The name Canberra comes from aboriginal language meaning the "meeting place." The city is located on a gently rolling plain surrounded by forested hills. In the heart of the town, an artificial lake - Burley Griffin Lake -is a reservoir created after the River Molonglo was dammed up.

\section{From the east to the west: Western Australia}

Geology of the Perth Basin. The Perth Basin is a north-northwesterly orientate drift basin on the western margin of Western Australia, adjacent to the Yilgarn Craton. The Perth Basin is a deep trough nearly $1,000 \mathrm{~km}$ long, that averages about $65 \mathrm{~km}$ in width, filled with sedimentary rocks. The total thickness of the Phanerozoic succession may exceed $15,000 \mathrm{~m}$. The basin contains up to $12 \mathrm{~km}$ of Ordovician and mid-Carboniferous to Cretaceous, primarily non-marine to shallow-marine strata, below an extensive thin, mostly non-marine, Cenozoic cover (Mory et al., 2005).

The eastern margin of the basin is defined throughout most of its length by the Darling Fault, which generally marks the connection between the Perth Basin and the Archaean Yilgarn Block. The northern part of the basin is bordered by 
a ridge of relatively shallow basement rocks that extend from the north. The western and southern offshore margins of the Perth Basin have not yet been precisely defined. The southwestern corner of the basin is bound by a narrow belt of Proterozoic granulite and gneiss in the Leeuwin Block.

Pre-Mesozoic stratigraphy includes Proterozoic siliciclastic sedimentary rocks, the Silurian

Tumblagooda Sandstone, as well as a well-developed Permian succession, that comprises nine formations over at least 2,600 m. Within the Mesozoic, the Triassic succession varies between continental and marine, and is of a similar thickness to the Permian sequence. The mainly continental Jurassic sediments are widespread throughout the basin, and are believed to be at least 4,200 m thick. The Perth Basin Cretaceous succession, which may be as thick as $12,000 \mathrm{~m}$, comprises a lower continental unit, a mixed continental, paralic and marine unit, and a lower marine unit, which are separated by unconformities. A well-marked unconformity occurs within the continental to paralic sequence of the Lower Cretaceous. Tertiary marine sediments up to $600 \mathrm{~m}$ thick occur beneath the Perth area and over much of the continental shelf (McPherson, Jones, 2005). The Quaternary sedimentation of the Perth Basin is represented by thin, impermanent sand dune systems, biogenic limestones, sandstones and some shales deposited during the last $\sim 20$ million years and during the ice ages (Playford et al., 1976). Thicknesses of Tertiary/ Quaternary deposits in the region generally increase to the west and north (McPherson, Jones, 2005).

\section{Perth}

Western Australia is the largest state in the country with the capital city in Perth. The distance between Perth and Sydney exceeds 3,290 km, so it is best to cover it by plane. Western Australia is a region where settlement developed relatively late. Perth, the capital of the state, with a population of 2 million people, has grown from a small provincial town. It is the most isolated city in the world - the distance to the nearest metropolis, Adelaide, amounts to 2,400 km. Perth is located on the Swan River. It is here that Australia's business centre with all the skyscrapers is situated. The center can be admired from Kings Park on the opposite bank of the river. The area of the park exceeds 1,000 acres. Within the complex, one can see a botanical garden with over 2,500 different species of plants that grow in Western Australia. A special attraction is the magnificent specimen of the adansonian tree brought here from the north.

Western Australia is one of the world's greatest treasure chests of minerals. Prehistoric rock formations contain deposits of silver, gold, nickel, iron ore and diamonds. The bedrock of the ocean contains a wealth of pearls and millions of cubic meters of natural gas. In connection with the wealth of minerals, Perth is the headquarters of many oil and mining companies, which occupy the skyscrapers in St. George's Terrace. The geological attractions of the area (at least a 2-hour drive from Perth) include the Parnululu National Park (Bungle Bungie), Wave Rock (a huge 15-metre high granite block which took shape as a result of erosion lasting 3 billion years) located $350 \mathrm{~km}$ east from Perth, and the Yalgorup National Park. Due to time limitations and relatively close distance, the author of the article managed to visit only the Yalgorup National Park.

\section{Yalgorup National Park}

The Yalgorup National Park lies on the western edge of Swan Coastal Plan near Mandurah. The name Yalgorup is derived from two Nyoongar Aboriginal words: Yalgor, meaning 'a swamp or lake' and Up, meaning 'a place of'. It is an appropriate name, because the park has 10 lakes that run in a chain. This park was formally established in the 1970 s to protect the costal lakes, swamps and tuart woodland between Mandurah and Myalup Beach. The soils of YNP originated from the sea, mostly consisting of calcareous material, derived from sea shells and other marine organisms. These soils, deposited in a series of dune ridges parallel to today's shoreline, illustrate the past changes in sea level. As the polar ice caps grew during the last ice age, about 130000 years ago, the sea level fell. About 18000 years ago, the level was 130 meters below its present point. The ice age ended about 10000 years ago, causing the sea level to rise, producing the shoreline we can see today.

The dune system at Yalgorup National Park is a result of these changes. The limestone rock and soils on the surface, inland from the coast, are derived from the older Spearwood dune system, which formed in the past 10000 to 140000 years. Yalgorup has 10 lakes that form three distinctive lines parallel to the coast. Lake Preston is extremely elongated and lies closest to the coast. The lakes behind the next ridge are far more broken up, comprising Swan Pond, Duck Pond, Boundary Lake, Lake Pollard, Martins Tank Lake, Lake Yalgorup, Lake Hayward and Newnham Lake.

YNP protects not only the lakes and the water bird habitat. It is also significant, because it provides a unique opportunity to see what life was like at the dawn of time. Rock-life structures, known as thrombolites, are on the edge of Like Clifton (Fig. 13). Like the famous stromatolites of Hamelin Pool, in Shark Bay, the thrombolites are built by microorganisms too small for the human eye to see. Within these structures of Lake Clifton, there are communities of diverse creatures living with population densities of 3000 per square meter. Lake Clifton is one of only a few places in Western Australia where living thrombolites survive. The thrombolite-building microorganisms of Lake Clifton resemble the earliest forms of life on Earth. These organisms were the only known form of life on Earth from 650 million to 3,500 million years ago. The thrombolites and stromatolites which they constructed dominated the clear, shallow seas of this period and formed extensive reef tracts rivaling those of modern coral reefs (www.dec.wa.gov.au). 


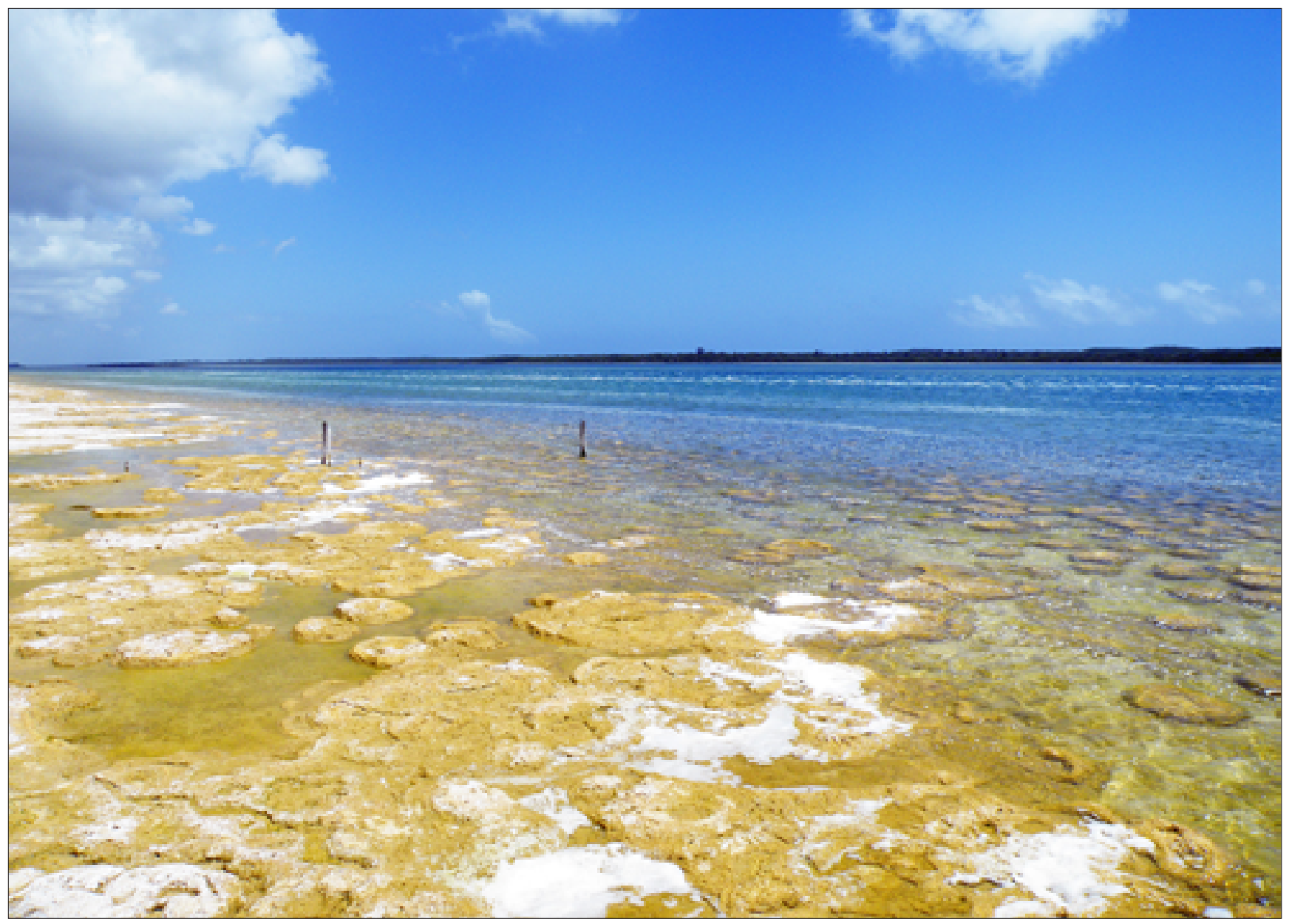

Fig. 13. Rock - life structures - thrombolites, Lake Clifton, photo I . Jamorska

\section{References}

Blewett R.S., Kennet B., Huston D.I., 2012. Australia in time and space. In: Blewett R.S. (ed.), Shaping a nation: A geology of Australia. Geoscience Australia, 2: 47-119.

Gostin V.A., 1966. Tertiary stratigraphy of Mornington District. Royal Society of Victoria, 79: 459-512.

Holdgate G.R., Gallagher S.J., 2003. Tertiary a period of transition to marine basin environments. In: Birch W.D. (ed.), Geology of Victoria. Geological Society of Australia Special Publication, 23: 289-335.

Keble R.A., 1950. The Mornington Peninsula. Geological Survey of Victoria. Department of Mines, Melbourne.

McPherson A., Jones A., 2005. Perth Basin geology review and site class assessment:. In: Jones T., Middelmann M., Corby N., Natural hazard risk in Perth, Western Australia: comprehensive report, Appendix D: 313-342.
Mizerski W., 2006. Geologia regionalna kontynentów. Wydawnictwa Naukowe PWN, Warszawa.

Mory A.J., Haig D.W., McLoughlin S., Hocking R.M., 2005. Geology of the northern Perth Basin, Western Australia - a field guide. Geological Survey of Western Australia, Perth.

Playford, P.E., Cockbain A.E., Low G.H., 1976. Geology of the Perth Basin Western Australia. Geological Survey of Western Australia, Perth.

\section{Websites}

www.australianalps.environment.gov.au

www.dec.wa.gov.au

www.nsw.gov.au

www.parkweb.vic.gov.au 